This item was submitted to Loughborough's Research Repository by the author.

Items in Figshare are protected by copyright, with all rights reserved, unless otherwise indicated.

\title{
Czech Republic: the rise of populism from the fringes to the mainstream
}

PLEASE CITE THE PUBLISHED VERSION

https://www.routledge.com/Populist-Political-Communication-in-Europe/Aalberg-Esser-Reinemann-

Stromback-De-Vreese/p/book/9781138654792

\section{PUBLISHER}

(c) Taylor \& Francis (Routledge)

\section{VERSION}

AM (Accepted Manuscript)

\section{PUBLISHER STATEMENT}

This work is made available according to the conditions of the Creative Commons Attribution-NonCommercialNoDerivatives 4.0 International (CC BY-NC-ND 4.0) licence. Full details of this licence are available at: https://creativecommons.org/licenses/by-nc-nd/4.0/

\section{LICENCE}

CC BY-NC-ND 4.0

\section{REPOSITORY RECORD}

Cisar, Ondrej, and Vaclav Stetka. 2019. "Czech Republic: The Rise of Populism from the Fringes to the Mainstream". figshare. https://hdl.handle.net/2134/22426. 
This is an Accepted Manuscript of a book chapter edited by Toril Aalberg, Frank Esser, Carsten Reinemann, Jesper Strömbäck, and Claes H. de Vreese published by Routledge as Populist Political Communication in Europe on July 26, 2016. The book is available online at: http://www.tandfebooks.com/doi/book/10.4324/9781315623016

\title{
22 Czech Republic. The Rise of Populism From the Fringes to the Mainstream
}

\author{
Ondřej Císař and Václav Štětka
}

\section{Introduction}

Existing scholarship on populism in the Czech Republic is limited, since the phenomenon of populism has not been a prominent feature of the Czech political system. 1 That said, in retrospect, populist features could be attributed to some political parties on the extremes of the political spectrum following the fall of Communism in the 1990s (see below). The actual term "populism" was not systematically used either in public discourse or in academic discourse before 2010. Thus, the academic research dealing specifically with populism in the Czech Republic that has been published so far is largely limited to the newest wave of populism (with only a few exceptions; see Pitrová, 2007). This wave, which in the view of some observers has significantly transformed the established party system in the country (Hanley, 2014; Havlík, 2015), arrived only with the 2013 parliamentary elections, leaving insufficient time for serious academic reflection. Given the relative scarcity of research on Czech political populism within the field of political studies, it does not come as a surprise that studies on populist political communication number even less. Indeed, the research field of political communication is severely underdeveloped in the country, with only a handful of scholars at two or three academic institutions attempting to pursue this line of research. Despite these challenges, it is our aim to map out the state of knowledge on populism and populist communication in the Czech Republic, which will hopefully also serve as a springboard for further academic explorations in this undoubtedly topical area of enquiry. Ongoing research is especially important given the recent developments on the Czech political scene, which suggest that populism will be a significant force to contend with in the near future.

\section{Research on Populism in the Czech Republic}

It is difficult to present a country-specific view on populism. First, there is nothing like a country-specific definition. As a result, internationally shared attributes of populism - such as anti-elitism or charismatic leaders' calls for direct rule by the people-are typically also used for its definition in the Czech Republic (a comprehensive debate on international research and the many attributes of populism can be found in Dvořáková, Buben, and Němec, 2012, one of only a couple of monographs written by domestic scholars that systematically deal with this phenomenon). Second, there is an implicit dispute within Czech political science scholarship as to the notion of populism itself. Since most the local political science researchers have traditionally sided with post-1989 right-wing parties, most notably the Civic Democratic Party (ODS), the recent emergence of new populist parties - which are currently taking political space at the expense of the Civic Democratic Party (among others) - has resulted in scholars providing a de facto defense of "traditional" politics (it is symptomatic that the Civic Democratic Party itself has been led by a professor of political science since 2014). Nevertheless, some of the work by authors by these scholars strives to be empirically based and analytical (see, e.g., Havlík, 2015; Havlík et al., 2012). 
Another approach to the study of populism draws on both political theory and a more systematic comparative analysis (see Dvořáková et al., 2012). Unlike the previously mentioned school, academics pursuing this line of research are generally closer to the political left, and analytically, they are more deeply grounded in critical political theory. Consequently, they aim at uncovering the strategic employment of populism in political actors' rhetoric and at a theoretically more robust understanding of the phenomenon. As a result, these researchers do not attach a populist label to a particular group of existing political parties but see populism more as a universal rhetorical device penetrating large parts of Czech political discourse. One of the co-authors of the above-cited monograph, Radek Buben, summed it up recently in an interview:

Populism is currently substituting communism in its role of a universal specter. Anybody who is disliked by a certain political player is labeled a populist. However, any political campaign is populist by definition. The word itself denotes the meaning of somebody mobilizing public support. In this understanding, populism is part of every politics. (Gruber, 2013, para. 1)

Generally it can be said that the most research on populism has been done within the field of political science, although not all of it is explicitly framed as research on populism. Most of the available scholarly literature is largely descriptive, focusing on ideology, programs, and the organizational structures of populist parties (Hanley, 2012b; Havlík, 2015; Havlík et al., 2012; see also Kouba, Císař, \& Navrátil, 2015). Existing contributions are mostly based on case-study research; some cross-party comparative work is available, but cross-country comparisons are rare (see, e.g., Hanley \& Sikk, 2014). Some work examines voters and their general characteristics (e.g., Linek, 2012), without, however, being explicitly focused on populism and its support among the Czech electorate (for an exception, see Havlík \& Hloušek, 2014).

Populist features could be attributed in the past to the far-right party Coalition for the Republic-Republican Party of Czechoslovakia (SPR-RSČ) (which reached the peak of its popularity in the mid-1990s) (Hanley, 2012a) or to the direct heir to the pre-1989 ruling party, the Communist Party of Bohemia and Moravia (KSCM). However, the term "populism" was haphazardly used prior to 2010. That year witnessed the rise of the newly formed party, Public Affairs (VV), the first party to successfully adopt an explicitly populist strategy in the form of anti-establishment and anti-corruption rhetoric, which formed the core of its program (Hanley, 2012b; Havlík, 2015).

Inspired by its electoral success, albeit only short-lived, other populist parties followed in the footsteps of Public Affairs in the 2013 parliamentary elections (Havlík et al., 2014). Two populist parties entered parliament, with the runner-up party, Action of Dissatisfied Citizens 2011 (ANO 2011 [Ano means "yes" in Czech]), becoming a member of the coalition government (with close to $19 \%$ of votes) and currently being the most popular party in the Czech Republic according to the polls (reaching 30\% of the vote in January 2015 among decided voters). In addition to the electorally strong ANO 2011, populist parties also include Dawn of Direct Democracy (USVIT, which achieved almost seven percent of the vote in the last elections, although its support has dwindled in the meantime) and the Free Citizens Party (SSO, a non-parliamentary party with just one member in the European Parliament; only one percent of the electorate supported the party in the polls in January 2015). As already mentioned, on the nominally left-side of the spectrum sits the Communist Party of Bohemia and Moravia (with almost $15 \%$ of the vote in the last elections). 
The current proliferation of populist parties in the Czech Republic is generally attributed to the population's growing dissatisfaction with post-1989 party politics, particularly with the corruption scandals associated with the traditional parties (Hanley, 2014). Scandals were most visibly exemplified by the Civic Democratic Party - first, at the end of the 1990s, resulting in the demise of then-prime minister Klaus (see Linek, 2010), and for the second time, in 2013, when major scandals brought an end to the party's hegemony on the right side of the political spectrum (the electoral support of the party subsequently evaporated; while it still managed to win the 2010 elections with $20 \%$ of the vote, in the 2013 elections, the party received less than eight percent).

If we follow Jagers and Walgrave's typology (2007), we can recognize different populist actors on the contemporary political scene in the Czech Republic, most having emerged in recent years. We start from what Jagers and Walgrave have termed an anti-elitist form of populism, which is represented by the most important populist party currently, ANO 2011. This party was founded in 2011 by Babiš, the second-richest Czech entrepreneur and the owner of the country's largest agricultural and food processing holding, Agrofert (which is also active in multiple other business sectors, including the news media). ANO 2011 repeatedly refers to "the people" and attacks the political elite; at the same time, it is not explicitly exclusionary. The party's political discourse consists of two main components: (a) opposition to an ineffective and corrupt political elite, and (b) a belief that a competent leader and his party managers will lead the "hard-working people" (who are contrasted to the elite) more effectively than the current elite. 2 Unlike Babiš and his followers, the political elite is presented as lazy and corrupt; after more than a year as finance minister, Babiš still used every opportunity to publicly express his contempt for professional politicianshence his mantra, "I am not a politician." Consequently, politics and compromises are empty words to him, since real-life experience is associated solely with the allegedly rational functioning of the private sector, which, in fact, serves as the desired model for his concept of politics (Císař, 2013).

As a result, the core of ANO 2011's program has so far been to substitute management for politics - literally, to "manage the state as a firm," as is repeatedly stressed by the party leader. In this rhetorical construction, the manager is not only rational and effective, but he is also closer to his employees than a politician is to his voters. Like a caring boss-a metaphor that resonates in the Czech public discourse (cf. the historical example of Bata and his industrial empire in Zlín) - Babiš plans to take care not only of all but of each and every individual. A suitable political solution is to be found neither on the left nor on the right; according to Babiš, we need a rational managerial approach, a technocratic formula that will streamline the functioning of public administration.

Moving further to the right on the political spectrum brings us to what Jagers and Walgrave called a complete form of populism, which is based on appeals to the people, anti-elitism, and the exclusion of out-groups. As we have already mentioned, the current wave was started by the Public Affairs party, whose discourse centered on anti-corruption, direct democracy, and social renewal (Hanley, 2012b; Havlík \& Hloušek, 2014; Linek, 2012: 170-172; Spáč, 2013). Simultaneously, it was directly aimed at the current political elite, which consisted of "dinosaurs" to be replaced by this project of newness (Sikk, 2010). Zero tolerance for those who were unable to "fit" into society (the unemployed, drug addicts, etc.) broke into the party's discourse, mirroring the population's fears and sentiments, which have been 
fully expressed by later populist parties, which followed the mobilization of Public Affairs. The party completely disintegrated during its first term in parliament (and as a minority coalition partner in the right-wing government of Nečas from the Civic Democratic Party) after a series of internal scandals and fights.

Dawn of Direct Democracy is another political project, but of a somewhat different kind than ANO 2011. Dawn of Direct Democracy was established by Okamura, a businessman and, until March 2015, the party leader. Okamura was vocal in public discourse before he established his party; he published books on governance and promoted direct democracy as a corrective to the corrupted regime of representative democracy. Although the structure of his program is similar to Babiš's, he is much more concerned with the not only hard-working but also culturally defined nation than with business-like effectiveness. As a result, his public discourse is aimed against foreign elements in the Czech nation and immigration in general. In particular, Okamura was able to skillfully exploit the Czech people's obsession with individual success as a defining moment of a person's general worth, which can definitely be traced back to the very beginning of the 1990s and the neoliberal discourse introduced originally by Klaus (see another version of the same metaphor in the discourse of the Free Citizens Party, below). Therefore, anybody who appears in a socially difficult situation is to be personally blamed for it, and his or her lack of success is the ultimate proof that this person is unable to adapt. In other words, he or she is unadaptable - a generally used label for unemployed, poor, or socially excluded people, often ethnicized in the form of the Roma community.

A very similar rhetoric - although with an even bigger emphasis on formally defined liberty as private ownership - can be found in the program of the Free Citizens Party. This party (not represented in the national parliament, but with one member in the European Parliament) is not usually categorized as populist, but it seems to fit the categories applied here relatively neatly. The party takes formal liberty as the only value worth pursuing, without any regard to its potential real-world consequences. In its political imagination, a paradise of liberty would ensue if there were as few rules as possible at the state level and, above all, at the EU level. The party strongly supports traditionally conceived sovereignty and the departure of the Czech Republic from the European Unions. In this sense, it is anti-elitist, placing the Czech nation against the EU's supposedly coercive powers. The existing political structures and their excessive regulation limit people's liberty and almost turn them into serfs since they are coerced to pay taxes, contribute to public budgets (even at the EU level), and behave according to an ever-increasing number of rules regulating human affairs. In fact, the Free Citizens Party strives for the Hobbesian state of nature, where the only rule obeyed is the right of the strongest, excluding all those who cannot succeed in the contest.

As we move to the left, we find what Jagers and Walgrave conceptualize as excluding populism. Certain left-wing political forces whose reaction to the dissolution of MarxismLeninism after 1989 was to lean toward "social populism" enjoy this type of discourse, which emphasizes heavy state involvement in the capitalist economy and the exclusion of the exploiting class. The Communist Party of Bohemia and Moravia is a typical representative of this position (March \& Mudde, 2005). Parties that evince excluding populism remain nominally on the left due to their economic programs, but they are clearly authoritarian and conservative given their sociocultural orientation, which mirrors the values of predominantly older generations longing for the lost times of pre-1989 real socialism. However, these parties recently seem to also be enjoying increasing support from younger age cohorts. 
Finally, to complete the overview of parties displaying populist traits based on Jagers and Walgrave's typology, we ought to mention the Party of Citizens' Rights (SPO). This party was founded in 2009 in order to establish a new political platform for the ex-prime minister and then-aspiring presidential candidate, Zeman. The Party of Citizens' Rights - which, until 2014, existed under the name "Party of Citizens' Rights-Zemanovci"- -vaguely adheres to a social-democratic ideology (in line with its specific Eastern European version combining the left economic program with strong cultural conservatism; see, e.g., Marks, Hooghe, Nelson, \& Edwards, 2006; Rovny \& Edwards, 2012). It concentrated its entire program, however, on the promotion of its nominal leader, who was still enjoying considerable popularity among the citizens despite his long-term absence from high politics. Building on this support, Zeman eventually came to win the 2013 presidential election, symbolically elevating the status of his party, too. Although this status was not transformed into electoral success in the 2013 elections (the party received less than two percent of the vote), Zeman established himself as a prominent populist actor on the Czech political scene, using a rhetoric of strong antielitism (particularly aimed at journalists and intellectuals) and an ever more frequent language of exclusionary populism (aimed at various minorities and, most importantly, at immigrants and Muslims).

\section{Populist Actors as Communicators}

Studies on the communication strategies of Czech populist parties or on media representation of populism are mostly composed of students' master's theses (all of them published in Czech; e.g., Bican, 2013; Janáková, 2014; Musilová, 2011). The question whether there is a specific or unique style of communication among Czech political actors that can be defined as populist therefore still waits to be properly answered empirically. Concerning actors from the past that have been associated with populism, studies dealing with the Republican Party (SPR-RSC) as an early instance of a right-wing radical populist party on the Czech political scene have inevitably touched on its communication style as well as on the style of the party's leader, Sládek (see Mareš, 2000; Roubal, 2012). Having built his reputation as a skilled and provocative public speaker, he managed to capture the electorate's attention primarily through the rhetoric of anti-communism, anti-elitism, and social populism, including frequent racist commentaries directed against the alleged "criminality of the Gypsy population" (Mareš, 2011). The often shocking but undoubtedly well-thought-out remarks, which have also involved derogatory comments aimed at the new post-communist establishment by explicitly likening its representatives to the old order (see Hanley, 2012a), were also one reason why Sládek and his party were largely shunned by the mainstream media, forcing them to communicate with their electorate mainly through public meetings and party rallies.

The Public Affairs party has been described as a business-driven party whose communication strategy was crafted using a professional marketing approach. It took advantage of being among the first to adopt Web 2.0 tools for campaign communication in the country. During the campaign in 2010, the party combined attacks on all other parties with populist statements, while also offering popular and fresh faces. The party's founder and real boss, Bárta, managed the party from the backstage. Radek John - a wellknown writer, journalist, and TV personality - acted as the party chairman while surrounded by a pack of young female candidates who were promoted mainly based on their physical appearance. As one commentator described it, the party's campaign strategy "combined all attributes of personalization, media marketing, lack of ideological foundations ... and a strategic use of populism embodied in programmatic eclecticism" (Poláček, 2013, p. 102). The party's utilization of new media channels was one of the features that, alongside the rhetoric commonly employed by protest parties, led some scholars to link it to the Tea Party 
Movement in the United States (see Rees, 2010). As Rees pointed out, Public Affairs used Facebook more intensively than most other parties in the country during the 2010 election campaign.

The emphasis on the role of social media in political communication has probably been one of the elements distinguishing the majority of the Czech populist parties and actors from the non-populist or mainstream actors. In the 2013 parliamentary election campaign, populist parties largely exceeded the established ones in online mobilization on Facebook; the eventual runner-up party, ANO 2011, was by far the most successful in attracting new fans, with over 15,000 "likes" gained over the last two weeks of the campaign - ten times more than the winner of the elections, the Social Democratic Party (Štětka \& Vochocová, 2014). Virtually invisible before the 2013 elections, ANO 2011 now has the most Facebook fans of all the Czech political parties (96,000 in March 2015). Likewise, both Dawn of Direct Democracy as well as the Free Citizens Party managed to attract a considerable number of supporters on Facebook during the campaign (the fifth and third highest, respectively; Štětka \& Vochocová, 2014, p. 1369). Both leaders of the two most prolific populist parties, Babiš (ANO 2011) and Okamura (Dawn of Direct Democracy, until May 2015), have also established themselves as significant players on social media platforms. Okamura has built the second-largest fan base on Facebook among Czech politicians. Babiš has focused on Twitter as a communication tool, and, in particular, as an agenda-setting instrument. Despite not being especially active in tweeting, his account has the biggest number of followers of all Czech politicians (over 108,000 in March 2015), and his tweets are regularly reported and commented on by the mainstream news media.

However, the observations concerning social media skills and strategies do not seem to apply to current left-wing populist actors on the Czech political scene. For the Communist Party, the process of getting adjusted to the new online communication environment has been long and painful, and neither the party nor its individual representatives are making any meaningful impact on social network sites. Rather, they focus on more traditional communication platforms, such as party newspapers and public meetings. The new left-wing populist Party of Citizen Rights has occasionally been making online buzz, but mostly just on single occasions aimed at rallying support for its honorary chairman, the Czech president Zeman, rather than as part of any systematic communication strategy. President Zeman himself, whose rhetoric has recently been incorporating increasingly more populist traits, is no fan of social media and has instead been actively attempting to spread his often controversial ideas and provocative statements via traditional mass media.

\section{The Media and Populism}

As indicated in the previous section, the amount of empirical research on media and populism in the Czech Republic is negligible, consisting mainly of unpublished theses and dissertations, focusing predominantly on content analysis of mass media representation of populist/radical parties (e.g., Blailová, 2013; Bukáček, 2011). The questions of how populist actors and their communicative strategies resonate with journalistic media and of what the typical features of media discourse on populism are cannot therefore be answered with the help of empirical studies. We can only offer some indicative insight based on our own understanding of this issue. In general, it can be argued that the majority of mainstream news media do not deliberately serve as platforms for populism, and most of them would strive not to actively engage in populist discourse - with the possible exception of the tabloid press (dailies Blesk and $A h a$ ), which often inclines toward anti-elitism and the exclusion of out-groups (especially Muslims, and occasionally the Roma). Also, it has to be mentioned that while the editorial 
content of the established news media attempts to follow professional standards of journalistic coverage (sometimes more successfully, sometimes less so), the very same outlets, in their online editions, leave space for readers' blogs, many of which are not only populist in the general sense but often actively incite hatred (mostly against the Roma and Muslims). Some of these blogs are written by populist politicians themselves. This arguably hypocritical approach - formally abstaining from populism on the editorial level but allowing for the dissemination of populist and even racist discourse through the newspapers' blogosphere, thereby increasing the website's viewership as well as profits from the accompanying online ads - means that some of the biggest Czech news media are not merely silent conveyors but are, in fact, accomplices in the spreading of populist ideology and the rise of populist political actors.

The assessment of the role of Czech news media in aiding populism and populist actors is furthermore significantly complicated by the current ownership situation on the domestic news media market - namely, many news media outlets are in the hands of Babiš, the leader of ANO 2011, who is serving as minister of finance and as deputy prime minister since 2014. At the moment (December 2015), Babiš's corporation, Agrofert, controls two national newspapers (MF Dnes and Lidové noviny), including their related news servers (iDnes.cz and Lidovky.cz); a chain of free regional weeklies $(5+2 d n i)$; a national commercial radio station (Impuls); and a music cable TV station (Ócko). Having acquired the national newspapers less than five months before the 2013 parliamentary elections, he has been frequently accused of instrumentalizing these media to advance his own political goals and ambitions (see Hájek \& Štefaniková, 2014). While no systematic empirical analysis has so far been conducted on this particular issue, anecdotal evidence leaked from the editorial room or from occasional probes into content indicates that a link does indeed exist between news production and the owner's interests, even if it could be explained, to some extent, by the existence of selfcensorship on the part of the journalists themselves.

Having no direct possession of nationwide mainstream news media, the other main populist actors (Okamura/Dawn of Direct Democracy; Free Citizens Party; Communist Party; Zeman/Party of Citizens Rights) have to rely largely on alternative platforms for influencing the public agenda. Of the non-mainstream online news sites, Parlamentní Listy (Parliament Papers, http://www.parlamentnilisty.cz) has gradually established itself as one of the leading outlets for disseminating populist communication by frequently publishing content produced by the above-mentioned actors or their supporters (as well as other authors from both of the far ends of the political spectrum). Since the content of Parlamentní Listy is often reproduced by mainstream media (and social network sites), it is an influential agenda-setting tool, helping the populist actors to spread their message while bypassing editorial mechanisms of established newsrooms.

\section{Citizens and Populism}

Research that would shed more light on the demographic or attitudinal characteristics of voters of populist parties following the 2013 parliamentary elections is still in its infancy, as the post-2013 survey results have not yet been published. Only a short report is available online (Mazák, 2015), which demonstrates that the voters of ANO 2011 did not differ radically from voters in general, apart from being slightly younger (the party did not find much of support among retired voters). Otherwise, the party seems to have been able to mobilize support from across the whole population, regardless of sociodemographic profile. The electorate of Dawn of Direct Democracy, the other populist party that made an impact in the 2013 elections, appears to have been younger than average as well — this finding, 
however, is only provisional, given the small number of Dawn of Direct Democracy voters in the sample (Mazák, 2015).

As summarized above, ANO 2011 did not present itself as an ideologically defined party in the 2013 campaign (and still does not today); consequently, it recruited its support equally from left- and right-oriented voters: according to the above-quoted report (Mazák, 2015), $27 \%$ of its supporters who also participated in the previous elections (70\% declared their past vote) voted for the Social Democratic Party, 33\% voted for the two main right-wing parties, while 22\% supported the populist party Public Affairs. However, the report also shows that when looking at where ANO voters place themselves on the left-right scale, it is clear they lean toward the right, which might be surprising, given that the party has also recruited a substantial number of past Social Democrat voters. At the same time, this result demonstrates the extent to which the party has been able to attract citizens who were in the past dissatisfied with the performance of all established parties across the political spectrum.

The situation bears some resemblance to what has been known about the electoral base of the Public Affairs party in the 2010 elections, which also originated with dissatisfied voters who placed their trust in the party's charismatic leader, former investigative journalist Radek John. According to the available data (Havlík \& Hloušek, 2014, pp. 588-560; Linek, 2012, pp. 182183), Public Affairs voters did not come from any particular social or class background; they were younger, predominantly located at the center-right on the political spectrum, and their motives were political dissatisfaction, alienation from the established political parties, and seeing corruption as the most important problem of Czech society. It is not surprising that the anti-corruption and anti-establishment rhetoric of this new party, a key element of its marketing strategy, resonated well with the attitudinal profile of generally dissatisfied and alienated voters attracted by the promise of "newness" (Sikk, 2010).

Nonetheless, with regard to the lack of empirical research, it is hard to say anything determinate about the effects of populist communication in the Czech Republic in general. To our knowledge, no studies have thus far specifically dealt with the effects of populist messages on the general population, with citizens' emotions toward political actors, or with opinions and attitudes.

\section{Summary and Recent Developments}

This chapter cn only provide a basic introduction to the phenomenon of populist political communication in the Czech Republic, offering an initial mapping of this still largely uncharted research territory. As we have repeated throughout the chapter, there is still little empirical, researchbased, and theory-driven academic knowledge about populist parties and actors in the Czech Republic; there is even less information about their communication strategies and surrounding media discourses and virtually no information about their voters, at least in a form of published research output. The "good news"- at least from the point of view of populism scholars - is that we can most certainly expect an upsurge in the volume of research on these issues in the near future, given the freshness of the phenomenon that has emerged after the 2013 parliamentary elections as a truly major feature of the Czech political system (despite some historical predecessors). There is also a good reason to believe that it will not be a one-off instance of a populist rise-and-fall, but rather that populism, in one form or another, will continue to define the Czech political landscape and penetrate its communication environment in the years to come - even with changes to the map of populist actors and parties, as the most recent developments have indeed already indicated. Dawn of Direct Democracy witnessed an internal party coup in February 2015 and effectively 
disintegrated by May 2015, and new parties have been created on its ruins as this chapter was being completed. Striving to revive his progressively declining political fortune, the former party leader, Okamura, has in the meantime attempted to put himself on the forefront of the anti-immigration movement, which has been lately gaining momentum in the Czech Republic in reaction to the European migration crisis. Combining an anti-immigration, xenophobic discourse with strong anti-Islamic rhetoric, actively fueled by part of the mainstream media, this still fragmented but seemingly growing movement might soon become yet another key actor on the Czech populist scene. Meanwhile, Babiš's ANO 2011 continues to ride a wave of popularity, as does the leader himself. The polls repeatedly confirm Babiš as the most popular Czech politician - a result clearly unaffected by mounting criticism from not just his political opponents but also a civil society concerned about the threat to democracy from such unprecedented concentration of power in one person's hands and the related multiple conflicts of interest in which he and his party are apparently involved.

\section{Notes}

1. This chapter was written as part of two projects, both supported by COST CZ: "Social movements, activism and political populism in the Czech Republic" (PI: Ondřej Císař) and "Social media as platforms of political populism in the Czech Republic" (PI: Václav Štětka).

2. The first notion was illustrated by ANO 2011's slogan in the 2013 parliamentary elections campaign: "We are not like politicians. We work hard." The second notion can be seen in the party's slogan from the 2014 municipal and senate elections campaign: "Problem? [Several concrete problems were mentioned on billboards.] We will simply solve it."

3. In a newspaper interview published in January 2015 in the wake of the Charlie Hebdo attacks, Zeman expressed his belief that "everybody should live in their land of origin", including third-generation immigrants who, according to him, are not capable of adaptation and remain "genetically dependent" on countries where their ancestors came from (see Perknerová 2015).

296 Ondřej Císař and Václav Štětka

\section{References}

Bican, J. (2013). Populist movements in the Czech Republic. Master's thesis, Charles University in Prague, Faculty of Arts, Institute of Political Sciences, Prague, Czech Republic.

Blailová, A. (2013). The analysis of media representation of the nationalistic scene in the Czech Republic. Master's thesis, Zapadoceska univerzita v Plzni, Pilsen, Czech Republic.

Bukáček, M. (2011). Media representation of political radicalism in selected media: A content analysis. Master's thesis, Masaryk University, Faculty of Social Sciences, Brno, Czech Republic.

Císar̆, O. (2013,. ANO, budeme zklamáni! iHNED.cz. 7 October. Retrieved from http://dialog.ihned.cz/c1-60973740-ano-budeme-zklamani.

Dvořáková, V., Buben, R., \& Němec, J. (2012). Que el pueblo mande! Levicové vlády, populismus a změny režimu v Latinské Americe. Prague, Czech Republic: SLON.

Gruber, J. (2013). Politika je vždy populistická: Rozhovor s Radkem Bubnem. A2larm. 22 October. Retrieved from http://a2larm.cz/2013/10/politika-je-vzdypopulisticka/.

Hájek, R., \& Štefaniková, S. (2014). Czech Republic: New owners and newsroom changes. 30 September 30. Retrieved from http://en.ejo.ch/media-politics/media-ownershipnewsroom-change-czech-republic. 
Hanley, S. (2012a). The Czech Republicans 1990-8: A populist outsider in a consolidating democracy. In C. Mudde \& R. C. Kaltwasser (Eds.) Populism in Europe and the Americas: Threat or corrective for democracy? (pp. 68-87). Cambridge, UK: Cambridge University Press.

Hanley, S. (2012b). Dynamics of new party formation in the Czech Republic 1996-2010: looking for the origins of a "political earthquake." East European Politics, 28(2), 119143.

Hanley, S. (2014). Two cheers for Czech democracy. Politologický časopis-Czech Journal of Political Science, 21(3), 161-176.

Hanley, S., \& Sikk, A. (2014). Economy, corruption or floating voters? Explaining the breakthroughs of anti-establishment reform parties in Eastern Europe. Party Politics. Advance online publication. Retrieved from http://ppq.sagepub.com/.

Havlík, V. (2015). The rise of populism in the Czech Republic in the shadow of political and economic crises. In H. Kriesi \& T.S. Pappas (Eds.), European populism in the shadow of the great recession (pp. 285-311). Colchester, UK: ECPR Press.

Havlík, V., Eibl, O., Gregor, M., Gregor, K., Hrbková, L., Chytilek, R. ... Voda, P. (2014). Volby do Poslanecké sněmovny 2013. Brno, Czech Republic: Masarykova univerzita.

Havlík, V., \& Hloušek, V. (2014). Dr. Jekyll and Mr. Hyde: The story of the populist Public Affairs party in the Czech Republic. Perspectives on European Politics \& Society, 15(4), 552-570.

Havlík, V., Pinková, A., Balcere, I., Cholova, B., Smrčková, M., Spáč, P. ... Krašovec, A. (2012). Populist parties in East-Central Europe. Brno, Czech Republic: Masarykova univerzita.

Jagers, J. \& Walgrave, S. (2007). Populism as political communication style: An empirical study of political parties' discourse in Belgium. European Journal of Political Research 46(3), 319-345.

Janáková, B. (2014). Populism in political communication of political movement Úsvit prrimé demokracie Tomia Okamury. Master's thesis, Charles University, Faculty of Social Sciences, Institute of Communication Studies and Journalism, Prague, Czech Republic.

Kouba, K., Císař, O., \& Navrátil, J. (2015). The Czech political science: A slow march towards relevance? In B. Krauz-Mozer, M. Kułakowska, P. Borowiec, \& P. Ścigaj (Eds.), Political science in Europe at the beginning of the 21st century (pp. 63-85). Crakow, Poland: Jagiellonian University Press.

Linek, L. (2010). Zrazení snů? Struktura a dynamika postojů k politickému režimu a jeho institucim a jeho di̊sledky. Prague, Czech Republic: SLON.

Linek, L. (Ed.). (2012). Voliči a volby 2010. Prague, Czech Republic: SLON.

March, L., \& Mudde, C. (2005). What's left of the radical left? The European radical left after 1989: Decline and mutation. Comparative European Politics 3(1), $23-49$.

Mareš, M. (2000). Konstituování krajní pravice v českém stranickopolitickém systému. Vývoj SPR-RSC od přelomu let 1989/1990 do parlamentních voleb v roce 1992. Politologický časopis-Czech Journal of Political Science, 2000(2), 157-168.

Mareš, M. (2011). Czech extreme right parties an unsuccessful story. Communist and PostCommunist Studies, 44(4), 283-298.

Marks, G., Hooghe, L., Nelson, M., \& Edwards, E. (2006). Party competition and European integration in the East and West. Different structure, same causality. Comparative Political Studies, 39(2), 155-175.

Mazák, J. (2015, May 26). Voliči populistických stran ve volbách 2013: základní charakteristiky a uživání nových médií. Zpráva z výzkumu. Charles University in Prague, Faculty of Social Sciences, Institute of Communication Studies and 
Journalism, Political Communication Research Group [website]. Retrieved from http://polcore.fsv.cuni.cz/wp-content/uploads/2014/05/Volici_2013.pdf.

Musilová, M. (2011). The Public Affairs party from the perspective of the populism concept. (Master's thesis). Brno, Czech Republic: Masaryk University, Faculty of Social Sciences.

Perknerová, Kateřina. 2015. Zeman k muslimům: Když se neumíte adaptovat, vrat'te se domů. Deník 10. 1. 2015, retrieved from http://www.denik.cz/z_domova/milos-zeman-kdyzse-neumite-adaptovat-vratte-se-domu-20150110.html.

Pitrová, M. (2007). Populism in the first European elections in the Czech Republic. 11(0). European Integration Online Papers. Retrieved from: http://eiop.or.at/eiop/pdf/2007002.pdf.

Poláček, J. (2013). Personalisation in election campaigns in the Czech Republic.European View, 12(1), 11-19.

Rees, M. C. (2010). 2010: Comparing and Contrasting Věci veřejné in the Czech Republic and the Tea Party Movement in the USA. Contemporary European Studies, 2010(2), $17-29$.

Roubal, P. (2012). “Smést to všechno do Vltavy.” Proměny revolučního diskurzu Sdružení pro republiku - Republikánské strany Československa. Rozděleni minulostí. In A. Gjuričová, M. Kopeček, P. Roubal, J. Suk, \& T. Zahradníček (Eds.), Rozděleni minulostí. Vytvárení politických identit v České republice po roce 1989 (pp. 311-342). Prague, Czech Republic: USD AVCR.

Rovny, J., \& Edwards E. (2012). Struggle over dimensionality: Party competition in Western and Eastern Europe. East European Politics and Societies, 26(1), 56-74.

Sikk, A. (2010). Newness as a winning formula for new political parties. Party Politics 18(4), 465-486.

Spáč, P. (2013). New political parties in the Czech Republic: Anti-politics or mainstream? In G. Mesežnikov, O. Gyárfášová, \& Z. Bútorová (Eds.), Alternative politics? The rise of new political parties in Central Europe (pp. 127-148). Bratislava, Slovakia: Institute for Public Affairs.

Štětka, V., \& Vochocová, L. (2014). A dialogue of the deaf, or communities of debate? The use of Facebook in the 2013 Czech parliamentary elections campaign. Teorija in praksa, 6(2014), 1361-1380. 